\title{
Room Arrangement of Vernacular Dwelling in Mandailing, Indonesia
}

\author{
Cut Nuraini ${ }^{\# 1}$, Husni Thamrin ${ }^{\# 2}$ \\ \# Institute Technology of Medan, Faculty of Civil and Planning, Departement of Architecture \\ Gedung Arca Street No. 52 A Medan, North Sumatera \\ ${ }^{1}$ cnuraini@itm.ac.id \\ ${ }^{2}$ alfaladisa@gmail.com
}

\begin{abstract}
This study aims to examine the room arrangement of vernacular dwelling in Manambin villages with the status of huta induk (main village) especially in applying the Gradual Development System based on Bincar-Bonom (GDS-BB) principles and determine the characteristics of residential floor plan design or room arrangement based on GDS-BB.

The result shows that the design of floor plan dwelling or room arrangement in Manambin villages, has the same character with the floor plan dwelling or room arrangement in Singengu village (previous research). Room arrangement of vernacular dwelling on applying the principle of GDS-BB identified with three group of activities : 1) group of main activities such as parent and children bedroom, 2) group of supporting activities such as family room and staircase, and 3) group of service activities such as kitchen, dining room and bathroom. Parent bedroom as private room for senior is located in direction of bonom, while the private room for junior is in the direction of bincar. Family room as communal space is located in the middle area and more often used by women, and has several functions, for examples, as gathering room and non-permanent bedroom. The service room is located in the back side area but its development according to the direction of bincar, especially for the kitchen, while the bathroom is in direction of bonom. Another finding that has been found in all cases shows that the development of room arrangement with GDS-BB are always retain the old spaces or first room in the direction of bonom while new spaces or second and next room evolved towards bincar.
\end{abstract}

Keyword : $\quad$ Room Arrangement, GDS-BB, Vernacular Dwelling, Mandailing Society

\section{INTRODUCTION}

Nowadays, designing the residential in the form of mass housing has always designed by using common standards, without considering who is the man going to use. Every human being is considered to have the same needs even though every human being is unique and different. Human characters of different cultural backgrounds are different too causes the need of residential also be different according to the understanding possessed by the human each self. The imbalance between the designs offered by the needs of society can be seen from the tendency of many houses that changed the design by residents because of dissatisfaction with the design. This research is needed to determine the character of room arrangement of residential design in order to understanding inhabit process and use, so that every design can be applicable in accordance with the needs of the community itself.

The studies about the character of local dwelling in Indonesia has much been done by Dwijendra [1] and Wastika [2] which focus on dwelling and settlement in urban area and revealed the character of room and settlement layout and the aplication of local concept on room and settlement layout. Other researcher, Imriyanti et al [3], Surjono et al [4] and Sardjono [5] are focus on dwelling but different locus, there are in coastal area, island and village that revealed the room layout of traditional dwelling with local concept. Research related to how the model of development of dwelling in accordance to the philosophy of society and the most likely to be applied in the field is very rare. Local knowledge related to the development of dwelling design especially the room arrangement with the principle of Gradual Development System based on Bincar-Bonom (GDS-BB) is important to be revealed, even made new knowledge and introduced to the outside world as a genius loci. This potential knowledge should be the basis for any development of dwelling design of Mandailaing community wherever they are, so the unique characteristics of Mandailing occupancy not lost by the time especially due to globalization that unstoppable.

Basic research on Mandailing by Nuraini [6] was reveals the initial data of eleven indigenous villages in Mandailing Julu. Related research has been done on Singengu village, one of village in Mandailing Julu area, with two different focus, namely the formation pattern of occupancy by Nuraini et al [7] and spatial settlement 
[8]. Nuraini et al [7] found that the formation pattern of residential buildings forming marsiadopan (opposite or face to face) based on the philosophy of bincar-bonom. The spaces inside the house or room arrangement are also arranged according to bincar-bonom philosophy and built in by gradual development system. Nuraini et al [8] found that spatial Singengu village settlements are planned and designed based on bincar-bonom philosophy. Two studies conducted previously indicated that the principle of bincar-bonom not only found in Singengu village, but also likely to be found in other villages in Mandailaing Julu region, especially in other huta induk (mother village).

The results of previous studies and a number of problems that has been described in the background formulated the research problem as follows : 1) does the residential floor plan design or room arrangement in Manambin village also uses the principle of Gradual Development System based on bincar-bonom ?; 2) what kind of floor plan design or room arrangement characteristics of dwelling with the principle of Gradual Development System based on bincar-bonom has?

This study aims to : 1) examine the room arrangement of vernacular dwelling in Manambin villages with the status of huta induk especially in applying the principle of Gradual Development System based on bincarbonom (GDS-BB); 2) determine the characteristics of residential floor plan design or room arrangement based on GDS-BB.

\section{LITERATURE STUDIES AND METHODOLOGY}

The fundamental purposes of housing according to Mabogunje et. al in Zango and Agboola [9] are the provision of shelter for the performances of social activities, safety, security, space, privacy, and other purposes that promote good health and dignified living. In other research, Olotuah [9] explained that housing encompasses environment in which man lives and grows in response to both biological material as well as physical needs. In other case, Massaudi et al [9] supported Olotuah assertion which to perform its optimal goal, it must possess the minimum facilities needed for human health, body and spirit. Finally, housing is not only a container for live but also to be a process of creating conditions in which higher portion of man's life activities occurs therein, as Palen described in Zango and Agboola [9].

\section{A. Vernacular Architecture}

Rudofsky in Bhaswara [10] explained that the studies on vernacular architecture has been done since 1964 when Rudofsky described that vernacular architecture underlines architecture with character of anonymity, self build, sustainable sources and pragmatic of encountering environmental hindrances. Bhaswara [10] described that the caracter of self build has the same meaning with indigeneous or native, while sustainable sources has the same meaning as local material. Encountering environmental hidrances has the same meaning as local environtmen, while anonymity is a local knowledge which is formed from indigeneous, local material, and local environment. Thus, the anonymity appears by the ownership of vernacular design, not by individuals but by communities where the design is [10].

Researchs about vernacular architecture last ten years with diverse background has often been studied until this time. These indicated that vernacular architecture in every place must be revealed in order to find a new knowledge, especially local knowledge of the local vernacular buildings and hamlets could be integrated to urban areas with appropriate development techniques. The studies on vernacular in urban area focus on housing development board has been done by Chang [11] and found a vernacular based upon high-rise housing in response to the globalism. This study revealed that housing development board and planning reflect problems within the culture that creates them and not necessarily a failure of the vernacular idea [11]. Other studies on vernacular in urban area focus on the value of vernacular setting has been done by Costa and Batista [12]. This studies revealed how vernacular buildings and hamlets could be integrated to urban areas with appropriate development techniques [12].

Other researcher, Paranagamage [13] explores whether there are types with distinctive spatial networks among the diverse house forms and the nature of embodied social norms. Houses are distinctively organized spatial networks that embody social norms and meaning of a given culture. Normally, it is accepted that visually identifiable house types which also closely fit the culture of a group are adopted by society [13].

The other studies on vernacular by Kamalipour \& Zaroudi [14] focus on urban consider the spatial configuration and morphology of the vernacular urban housing in relation to the conceptual framework. These study based on sociocultural contex. The findings indicates the complexity of relations between multilayered hierarchies of sociocultural factors and urban housing form in terms of physical form and spatial configuration in the case study of vernacular housing [14]. The other studies on vernacular architecture by Soewarno [15] focus on urban based on a transformation of vernacular buildings revealed that the background of historic, cultural and religious issues has little affects in the transformation of buildings in modern cities. For some inhabitants, especially the Chinese communities, they also represent the ancestor's tradition and culture which are more historical and irrelevant in the modern world [15]. In the other focus, Verderber [16] findings the commercial vernacular building type and revealed an environmental cognition theoretical perspective to the 
study of commercial vernacular architecture in North America. More specifically, it is the first time Attention Restoration Theory (ART) and the concept of automaticity, as embedded within environmental cognition theory and research, has been applied to further understand the enduring and repetitive-exposure psychological importance of these structures and their immediate installation contexts [16].

The studies on vernacular in rural area, informal settlement or village has been done until this time. Dhote, Onkar and Das [17] explained about what once called a 'house of all seasons' has now been christened 'climateconscious', 'bioclimatic', energy-efficient' or 'sustainable' architecture. These terminologies are just not a welter but have definite meaningwith respect to context at given point of time. The researchers comprises the typology of settlement pattern with reference to physiographic features, site selection with appropriateness to respond to local climate and spatial organization of settlement to suit the functional need. Then, the researchers found the underliying principles of sustainability of the settlement and habitate and can be applied in the modern context in order to achieve sustainable design solutions [17].

Vernacular architecture can be imagined as a living organism which is the outcome of centuries of optimization of topography adaptation, climate consideration, material use, construction techniques, ets as Yang \& Wang decribed [18]. Yang and Wang [18] explained that the environment and the multiple form of traditional dwellings reflect the balanced development of residential houses, cultural background, natural ecology, forming regional context and system. The exploration dan evaluation of sustainable vernacular architecture from a settlement layout, architectural form and natural architecture materials should be put forward the sustainable perspective. It also can be taken as an example for modern building and landscaping design [18].

Other researcher, Nia [19] revealed the principles which have characterized the architecture of vernacular residential structures of Lahijan (located in north of Iran called Shikili Houses) and can be integrated to the refurbishment of existing building or the design of new ones in traditional surroundings. It can be considered as living organism which are the inheritance of optimal use of materials, constructing methods and climatic considerations during centuries. This kinds of designing is based on the layout of the building, the spacing or site planning, the air movement, the openings or size positions and the building envelope.

While Nia [19] studied about vernacular residential structures, Moustafa [20] revealed the potential benefits of adopting aspects of vernacular architecture in allowing a higher and more sustainable quality of life in the residentail communities of Arid regions in Egypt. The study discourse how to achieve sustainable development of informal communities in accordance with the indigenous features of the local architecture of Arid region. Moustafa's research [20] aims to employ values of vernacular architecture in developing agendas for dealing with the informal settlements to provide sustainable communities and give some recommendations to help maintain the value of the vernacular architecture and distinctive social values, culture, and sustainable development of arid communities in Egypt [20].

If we back to the term of the vernacular architecture as Rudosfky in Bhaswara [10] described above, so the implication of vernacular architecture in Mandailing Julu village especially in Manambin influenced of indigeneous by communities which is concerned with room arrangement of local dwelling and it processes. The anonymity appears by the communities where the design is.

\section{B. Bincar-Bonom Theory}

Bincar-bonom is a local theory of Singengu village settlement that has become a principle guidelines in arranging a living space in the residential areas [7][8]. Bincar, which means sunrise and bonom, which means sunset are not merely term to indicate the directions of sunrise and sunset but have becomes the base of forming singengu village spatial plan which is empirically translated in the form of placement, setting or location of physical elements of settlements in the three spatial scale in such away. Thus, it is always on the bincar bonom axis with an emphasis on three important relations, i.e. the relation between people, present day people to the ancestors, and all people to the Creator. As a local theory, bincar is identical with youth, junior and new, while bonom is identical to the aged, senior and old [7][8]. The theory of Bincar-Bonom illustrated in Figure 1.
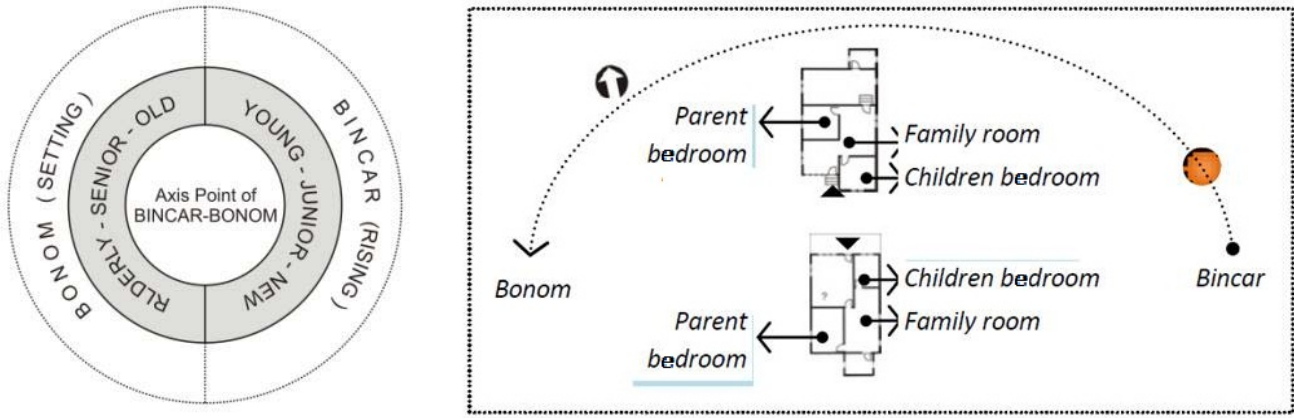

Fig. 1. The theory of Bincar-Bonom and the aplication of its on bedroom arrangement for parents and son in Singengu Village (Sources : Nuraini et al, 2014a) 


\section{Research Methodology}

This study used a combination of several methods according to the purpose of the research. Yin [21] and Groat \& Wang [22] explained how to choose a strategy of research related to the question What and How. The first research question related to 'does the residential floor plan design or room arrangement in other huta induk village customary in Mandailing Julu region also uses the principle of Gradual Development System based on bincar-bonom has been resolved through surveys, field observations and interviews. The analysis was performed with the deductive method which is based on previous findings in Singengu village to look for the facts in Manambin village how the aplication of GDS-BB is used. This finding was produces a more stable and complete the results of previous research than formulate the characteristic of room arrangement.

Methods of data collection according to research questions can refer to Howel [23], namely through surveys, structured interviews base on the control of the results of the first study (especially related to the location of room, function and nature), parsipatory observations (involved) and focus on heirlom houses in Manambin village with the status of huta induk.

Dwelling sampling determined by uses purposive sampling method which is a sample of dwelling selected as the unit of analysis must be in accordance with the criteria of dwelling that have been studied previously, the heirloom house (bagas pusako/rumah pusaka). In a previous study has been found ten heirloom house in the village but only eight unit can still be traced its gradual development. Landscape of Manambin is based on Nuraini [6] and the field survey carried out showed that there were nine houses in the Manambin as cases as illustrated in Figure 2.

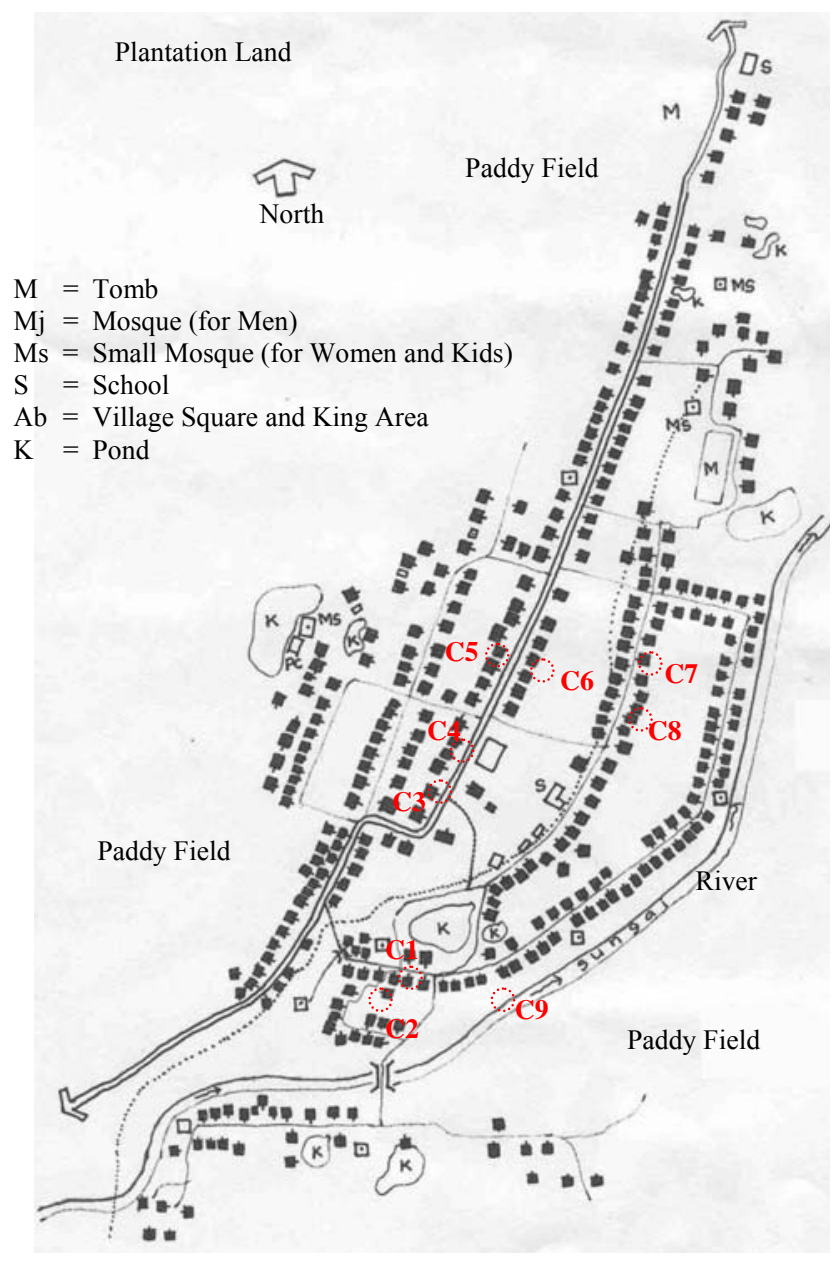

Fig. 2. Lansdcape of Manambin village and distribution of nine heirloom houses (Source : Redrawing by author based on Nuraini, 2004 and field surveys, 2016)

\section{RESULTS}

A Theorytical orientations showed that the implication of vernacular architecture in Mandailing Julu village especially in Manambin influenced by indigeneous by communities which is concerned with room arrangement of local dwelling and it processes. Vernacular architecture as descibed above shows that studied about the 
character of anonymity, self build, sustainable resources and pragmatic of encountering environmental hidrances can be taken as an example for modern design based on local knowledge.

The result shows that all of room arrangement of heirloom houses in Manambin has have the same trend with heirloom houses in Singengu village (previous research) especially in term of GDS-BB principles and the aplication of it. For more details, the aplication of GDS-BB principles on room arrangement of heirloom houses in Manambin village is described as follows :

\section{A. The Aplication of GDS-BB on Room Arrangement of Vernacular Dwelling in Manambin Village}

The history of nine cases of housing development in Manambin village shows that initially the houses only consisted of four rooms, there are the bedroom, the guest room, living room and the kitchen. Phase two is before the birth of a baby, the bedroom and the living room was expanded to the east or toward bincar direction and simultaneously towards to jolo or front area. Front area which the function as a guest room also expanded to bincar direction. Phase three, the kitchen was expanded to back side area dan built a new bedroom as addition by using a part of living room. This phase was done when the children grew up. On phase one to three, the houses is still pillar houses except the bathroom which has built on the ground. On this phase, most of the houses was built the bathroom on the ground, as found on $\mathrm{C} 1, \mathrm{C} 2, \mathrm{C} 3, \mathrm{C} 4, \mathrm{C} 7$ and $\mathrm{C} 8$ while the three other houses (C5, C6) was not. These phenomenon happened because of the bathing activity ussually done by the people in the public shower called pancur paridian on musholla area which scattered in the round of village.

The final of housing development phase shows the interesting phenomena. In this phase, all of the houses has built the new bedroom in the bincar direction. All of houses was retaining the position of the first bedroom on bonom area. All of cases shows the same trend of room setting for the parent and child, senior and junior, old and new, even elder and younger. Every first rooms was attempts the positions remains in bonom area while the new rooms was developed to bincar area.

The principle of GDS-BB which has been found in Manambin village shows that the gradual development in all of house design by the heirs not only suitable for the needs of space for a new family member, but also guided by the rule of bincar-bonom. Its has been guided a space for all residents. The aplication of GDS-BB on room arrangement of eight heirloom house in Manambin village should be seen on figure 3 dan figure 4.
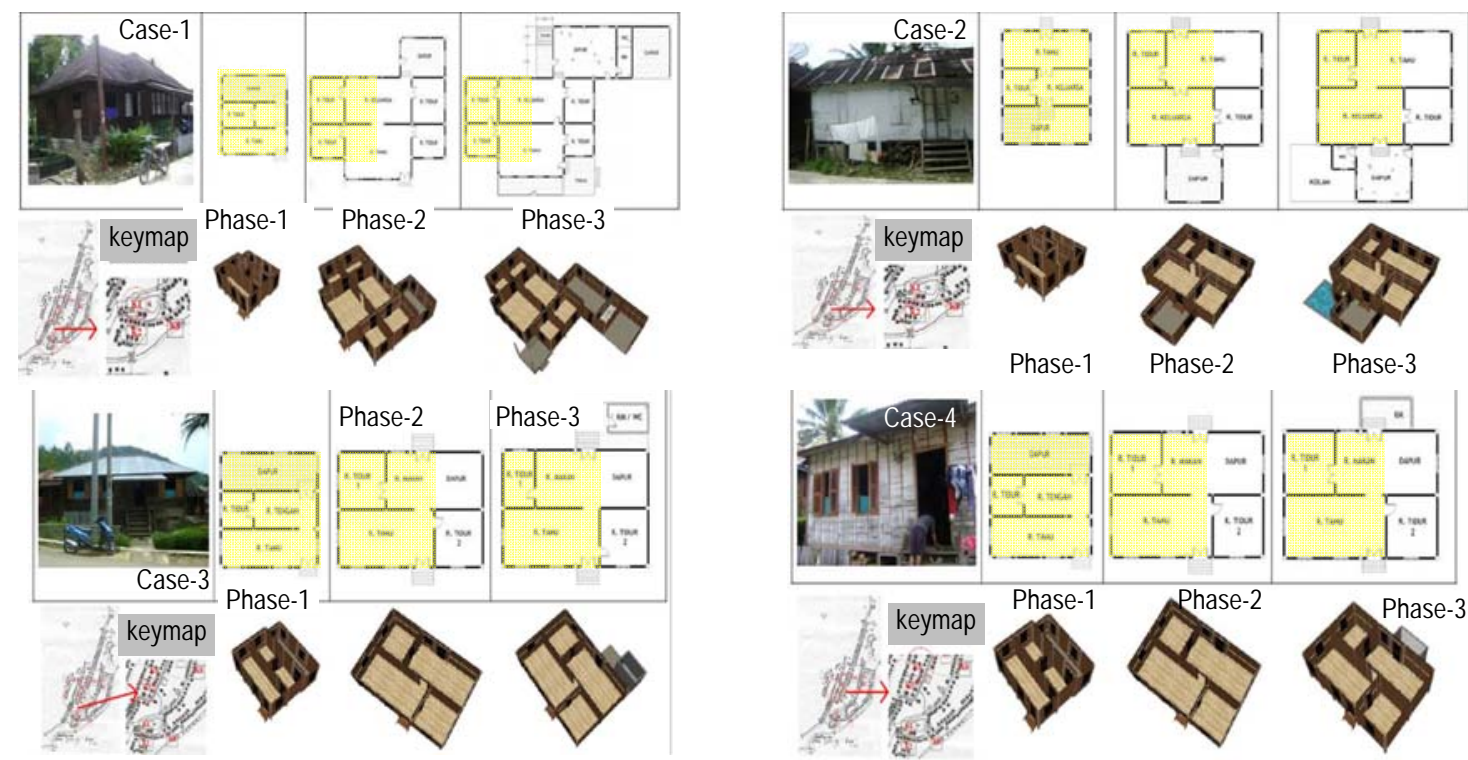

Fig. 3. The aplication of GDS-BB on room arrangement of four heirloom houses in Manambin village 

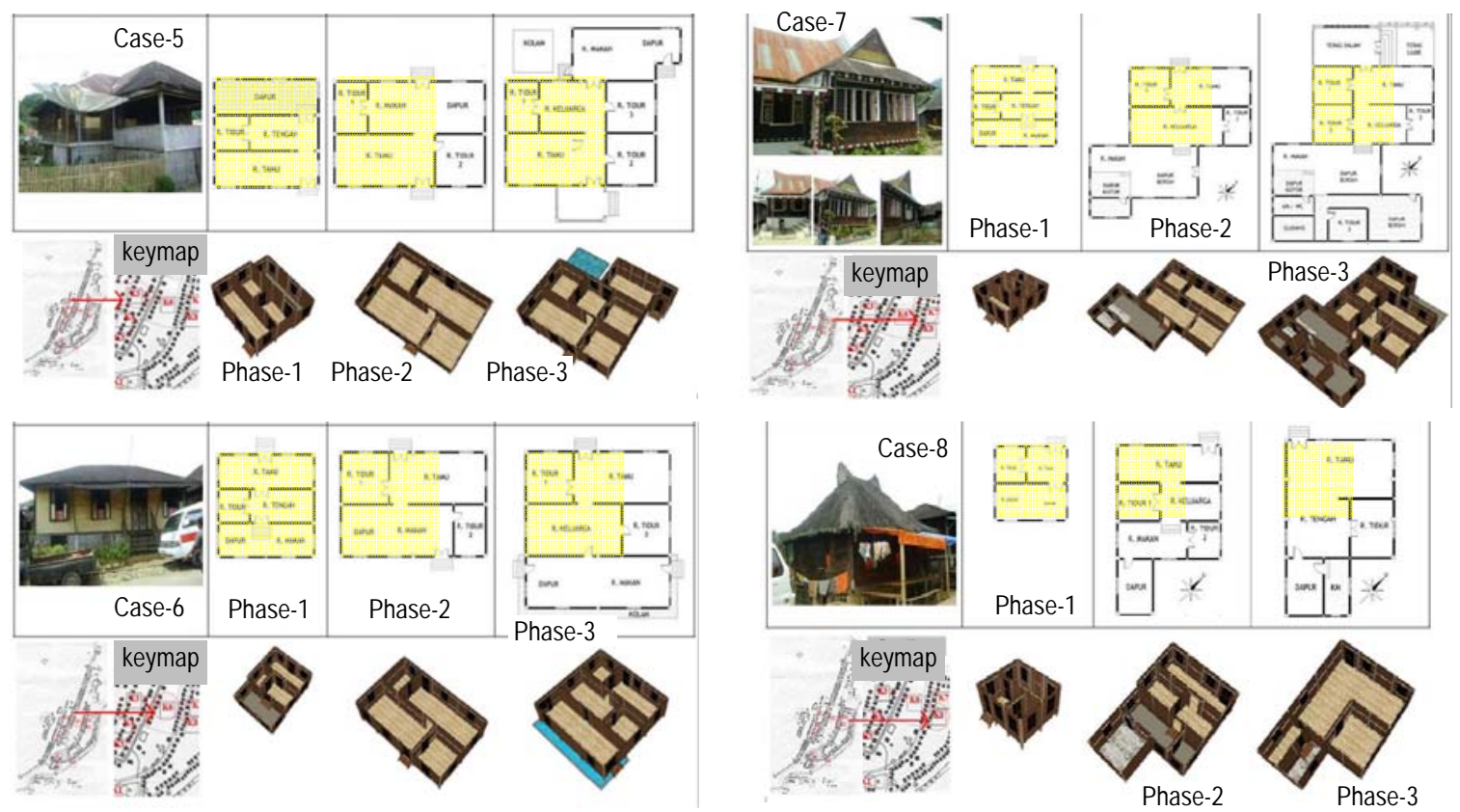

Fig. 4. The aplication of GDS-BB on room arrangement of four heirloom houses in Manambin village

\section{B. Room Arrangement of Dwelling with GDS-BB Principles}

The result shows that design of room arrangement of vernacular dwelling in Manambin village has a similar or analog character with room arrangement of vernacular dwelling in Singengu. All the room arrangement uses the GDS-BB Principles with with three group of activities as follows :

1) Group of main activities.

Main activities in dwelling is for rest or sleeping activities and determined with two group of room such as parent and children bedroom. Its arranged by GDS-BB principles with specific space and direction. Parent bedroom as private room for senior is located in direction of bonom, while the children bedroom as private room for junior is in the direction of bincar.

2) Group of supporting activities

Supporting activities in dwelling is for gathering and determined with two group of room such as family room and staircase room. Family room as communal space is located in the middle area as axis point of bincar-bonom. its more often used by women, and has several functions, for examples, as gathering room and non-permanent bedroom in the night for young men.

3) Group of service activities

Service activities in dwelling is for servicing the main and supporting activities and determined with three group of room such as kitchen, dining room and bathroom. Its arranged by GDS-BB principles with specific space and direction too. The service room is located in the back side area but its development according to the direction of bincar, especially for the kitchen, while the bathroom is in direction of bonom.

The interesting fact that has been found in case shows the Gradual Development System of dwelling based on bincar-bonom principles always maintained the first and past room di bonom area while the new room always develop to bincar direction. 


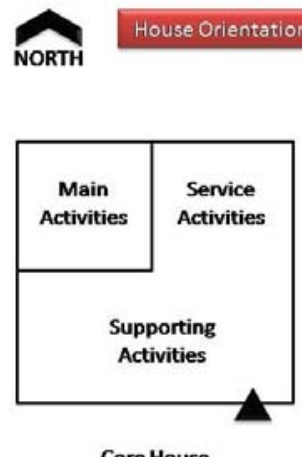

Core House

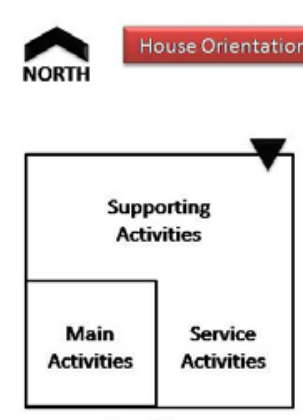

Core House

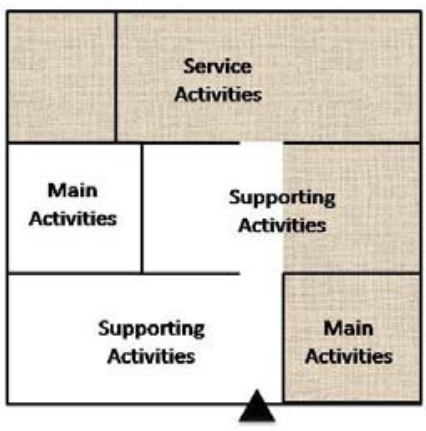

The Development

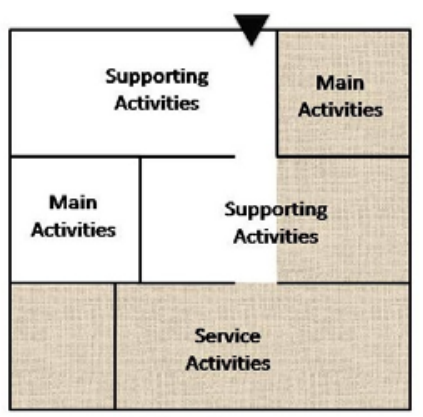

The Development
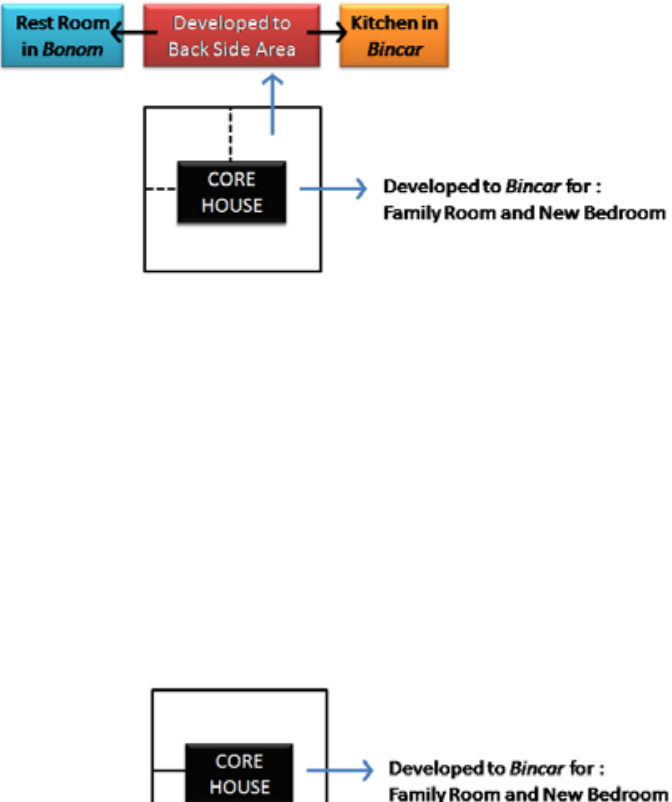

Family Room and New Bedroom

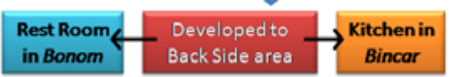

Fig 5. Three Group of Activities on Room Arrangement of vernacular dwelling in Manambin village, Mandailing with GDS-BB Principles and its development

\section{CONCLUSION}

The result shows that vernacular dwelling as heirloom house in Manambin absolutely using the GDS-BB when built the house. This finding shows and it is exacly confirm that GDS-BB principles become the basis of dwelling development of Mandailing society in Mandailing Julu area. Room arrangement of vernacular dwelling in Manambin village on applying the principle of GDS-BB identified with three group of activities as follows : 1) group of main activities such as parent and children bedroom, 2) group of supporting activities such as family room and staircase, and 3) group of service activities such as kitchen, dining room and bathroom. Parent bedroom as private room for senior is located in direction of bonom, while the private room for junior is in the direction of bincar. Family room as communal space is located in the middle area and more often used by women, and has several functions, for examples, as gathering room and non-permanent bedroom. The service room is located in the back side area but its development according to the direction of bincar, especially for the kitchen, while the bathroom is in direction of bonom. Another finding that has been found in all cases shows that the development of room arrangement with GDS-BB are always retain the old spaces or first room in the direction of bonom while new spaces or second and next room evolved towards bincar.

The characteristic of room arrangement in Manambin village has formed closely fit the culture and indigeneous. Room arrangement of heirloom houses in Manambin village revealed that a dwelling for a communities shoud be integrated with local knowledge even appropriate development techniques. Room arrangement of heirloom houses in Manambin can be imagine as a living organism which is the outcome of social values, culture, and religious issues.

Finally, the character of anonymity in vernacular architecture especially on room arrangement of dwelling distinctively organized spatial networks that embody social norms and meaning of a given culture. For Mandailing inhabitants, especially for Manambin village communities, they also represent the ancestor's tradition and culture which are more historical and relevant in the present world. The production space with room arrangements by the Mandailing people in Manambin becomes a role model of dwelling design and allowing a higher and more sustainable quality of life in their residential.

\section{ACKNOWLEDGMENT}

This research is part of a research funded by the DRPM Dikti of Republic of Indonesian through Competitive Grant Research (2016) and continued with Applied Product Research (2017). Therefore, the researchers would like to thank to the government of Republic of Indonesian especially the Directorate of Research and 
Community Service of Research and Technology Ministries who have provided competing grant research funds (2017) and applied product research (2017). The researchers also thank to the government of Mandailing Natal regency, the Kotanopan district government and all the informants of the heirloom house owners in Manambin village.

\section{REFERENCES}

[1] Dwijendra K A (2003). Perumahan dan Permukiman Tradisional di Bali, Jurnal Permukiman Natah, Vol. 1 No.1, Februari, 2003 , Fakultas Teknik Program Studi Arsitektur Universitas Udayana, Denpasar, Hal. 8-25.

[2] Wastika DN (2005) Penerapan Konsep Tri Hita Karana dalam Perencanaan Perumahan di Bali. Jurnal Permukiman Natah, Vol. 3 No. 2. Agustus 2005. Fakultas Teknik Program Studi Arsitektur Universitas Udayana, Denpasar, Hal. 62-105.

[3] Imriyanti, Amri N \& Paramitha A (2012) Metafora Desain Rumah Tinggal di Kawasan Wisata Pesisir Pantai Tanjung Bayang Makassar. Proseding Hasil Penelitian Fakultas Teknik Universitas Hasanuddin, Jurusan Arsitektur, Vol. 6 : Desember 2012, Group Teknik Arsitektur, ISBN. 978-979-127255-0-6, Hal. 1-12.

[4] Surjono, Pelangi SU dan Sari N (2012) Rumah dan Permukiman Tradisional Suku Bajau di Pulau Buton. Jurnal Tesa Arsitektur, Vol. 10, No. 2, Desember 2012. Program Studi Arsitektur, Fakultas Arsitektur dan Desain, Universitas Katolik Soegijapranata, Semarang, Hal. 62-72.

[5] Sardjono AB (2012) Konsep Keberadaan 'Halaman Dalam' Pada Tata Ruang Rumah Tradisional Kudus sebagai Inspirasi Rancangan Rumah Tinggal. Jurnal Tesa Arsitektur, Vol. 10, No. 2, Desember 2012. Program Studi Arsitektur, Fakultas Arsitektur dan Desain, Universitas Katolik Soegijapranata, Semarang, Hal. 73-83.

[6] Nuraini (2004) Permukiman Suku Batak Mandailing, Gadjah Mada University Press, Yogyakarta, Hal. 118-121.

[7] Nuraini C, Djunaedi A, Sudaryono dan Subroto YW (2014a) Bincar-Bonom as the Basis of house Formations in Singengu Village Settlement. Journal of Scientific Research and Studies, Vol.1 (6), December 2014, ISSN 2375-8791, http://www.modernrespub.org/jsrsjindex.htm, pp.118-130.

[8] Nuraini C, Djunaedi A, Sudaryono and Subroto YW (2014b) Bincar-Bonom : The Basis of Spatial Arrangements of Singengu Village, Indonesia. Journal of the International Society for the Study of Vernacular Settlements (ISVS e-Journal) Vol.3, No.2, December 2014, Publised on 2015, pp. 1-16.

[9] Zango, M.S., and Agboola, O.P., (2014). Development of Traditional Architecture in Negeria : A Case Study of Hausa House Form. International Journal of African Society Cultures and Traditions, June 2014, Published by European Centre for Research Training and Development UK (www.ea-journals.org), Vol.1, No.1, pp.61-74.

[10] Bhaswara R (2010) Reinterpretasi Arsitektur Vernakular : Humanis, Progresif, dan Kontekstual dalam Peradaban Manusia, Jurnal Arsitektur Universitas Bandar Lampung, Oktober 2010, Vol.1 No. 1, Hal. 10-15.

[11] Chang S (2000) A High-Rise Vernacular in Singapore's Housing Development Board Housing, Berkeley Planning Journal, 14 (1), pp. $97-116$

[12] Costa M Reimao and Batista D (2011) Towards Integrating Rural Vernacular Settlement in Urban Regions : A Study of Algarve, Protugal, Journal of the International Society for the Study of Vernacular Settlements (ISVS) e-Journal, Vol.2, Issue 1, June 2011, pp. 35-51.

[13] Paranagamage P (2013) Changing Boundaries and Meanings of Middle Class Houses in Sri Lanka, Journal of the International Society for the Study of Vernacular Settlements (ISVS) e-Journal, Vol. 2, No. 4, September 2013, pp. 1-21.

[14] Kamalipour H and Zaoudi M (2014) Sociocultural Context and Vernacular Housing Morphology : A Case Study, Current Urban Studies, 2, 220-232. http://dx.doi.org/10.4236/cus.2014.23022 Pp. 220-232.

[15] Soewarno N (2014) Transformation of Vernacular Buildings : Chinatown in Bandung City, Indonesia, Journal of the International Society for the Study of Vernacular Settlements (ISVS) e-Journal, Vol.3, Issue. 1, April 2014, pp. 42-49.

[16] Verderber S (2016) Learning from Commercial Vernacular Building Types : A north American Case Study, International Journal of Architectural Research (Archnet-IJAR), Vol. 10. Issue 2, july 2016, pp. 22-37.

[17] Dhote K K, Onkar P and Das S (2012) Identifying the Sustainable Practices from the Vernacular Architecture of Tribes of Central India, Journal of American Transactions on Engenering \& Applied Sciences, Volume 1 No. 3 ISSN 2229-1652 eISSN 2229-1660, pp. 237-251.

[18] Yang Z and Wang L (2012) Evaluation of Sustainable Vernacular Architecture and Settlements in Yunan, Journal of The Sustainable City VII, Vol. 2, WIT Transactions on Ecology and The Environment, Vol. 155, SSN 1743-3541 pp. 905-015.

[19] Nia E G (2013) Architectural Structure and Environmental Performance of Sustainable Lahijan Vernacular Settlements N Iran, International journal of Environmental Protection, Jan. 2013, Vo. 3 Iss. 1, pp. 15-23.

[20] Moustafa, W.F.O., (2014). Vernacular Architecture Approach to Achieve Sustainability In Informal Settlements. Proceeding of Word SB 14 Barcelona, ISBN: 978-84-697-1815-5, pp. $200-207$.

[21] Yin, R K., 2003. Studi Kasus : Desain dan Metode. PT. Raja Grafindo Perkasa, Jakarta.

[22] Groat L \& Wang D (2002) Architectural Research Methode. Jhon Willey \& Son, Inc., New York.

[23] Howel K E (2013) An Introduction to The Philosophy of Methodology, Sage, Los Angeles

\section{AUTHOR PROFILE}

Cut Nuraini Lecturer at Departement of Architecture, Institute Technology of Medan. Email : cnuraini@itm.ac.id

Husni Thamrin Lecturer at Departement of Architecture, Institute Technology of Medan, Email : alfaladisa@gmail.com 